\title{
The divinity of Jesus in the Gospel of John: The 'lived experiences' it fostered when the text was read
}

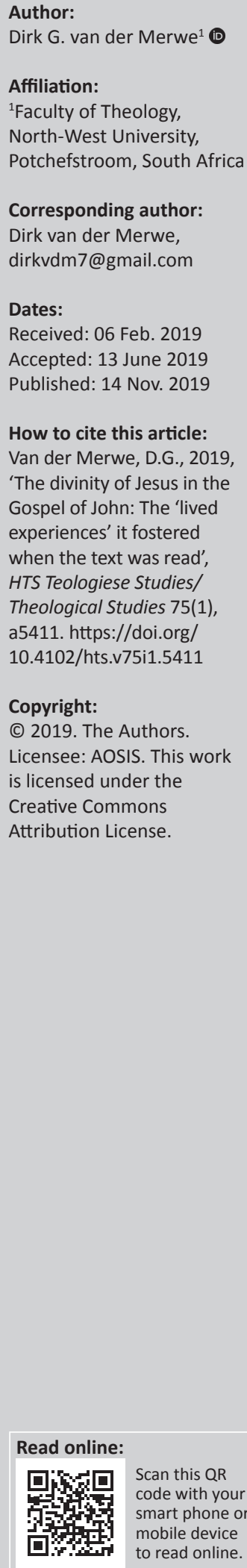

\begin{abstract}
The discipline, Christian Spirituality, evokes a new interest in Early Christian spirituality. What conceived spiritualities were fostered when the early Christians read the documents that were written to them and how did it influence them? According to Wolfgang Iser, a 'reader often feels involved in events which, at the time of reading, seems real to him'. This article looks into how John describes and explains the divinity of Jesus. It also attempts to determine conceived spiritualities (lived experiences) fostered when the early Christians read John. The article starts with a brief orientation of what it means when a reader becomes entangled in the reading of a text. Then some mechanisms, as proposed by Waaijman and Iser, that can foster spiritualities are employed to examine the text, including the interaction between the text and the reader; the creation of images; the dialectic between retention and pretension and the filling of gaps.
\end{abstract}

Keywords: Divinity; Jesus; Experiences; Hearer; Readers; Mechanisms.

\section{Introduction}

The New Testament presents us with ample evidence of how the early Christian writers honestly endeavoured to formulate their faith in Jesus and how they experienced him, what they wanted to say about his identity, his person and his work. If one tries to abstract from the New Testament a single, consistent view of Christ, it would have caused a distorted image of him. How can the 'finite' efficiently describe the 'infinite'? The gospels seem to picture the person of Jesus from different perspectives. The notion one gets of early Christian thinkers is that they struggle to find words that are adequate to express their experiences and faith in the incarnated God, or resurrected Christ (cf. Kysar [1976] 2007:38). John is one of the four canonical gospel expressions of Jesus who is the Christ, the Son of God (cf. Hurtado 2003:354).

Jesus, according to John, is the Word of God made flesh. With its well-designed and spiralling prose, John's prologue introduces the Word, through whom God created all things (Jn 1:3, 10), and the Word incarnated as a human being (Jn 1:1,14). The Word is God's way of communicating with humans, and John explains how this takes place in Jesus of Nazareth - through his teaching, his actions and his death. A theological tension unfolds the story. Readers will know from the beginning that Jesus is the Word of God, but those who meet Jesus during his ministry do not. Some are called by him and they follow (Jn 1:43), while others are initially impressed by his miracles but later find his proclamations to 'eat my flesh' (Jn 6:51) and to 'drink my blood' (Jn 6:54) incomprehensible and him 'making himself equal to God' (Jn 5:18) to be blasphemous.

In John's gospel, we meet a Jesus who is a 'puzzle'. He is undoubtedly human, yet is one with God. He is a rabbi who confesses to be a king, a healer who provides life by dying. The gospel presents Jesus to the readers in a number of familiar categories only to find out later that Jesus cannot be limited to anyone of them (Koester 2008:83). The Gospel of John's uniqueness in early Christian literature entails its special patterns of language ${ }^{1}$ to describe Jesus who is the Christ, the Son of God. Significant among these patterns is Jesus' depiction as the one who has descended from heaven and at the end of his mission reascends to the Father (Meeks 1972:44). John can help the reader to see and to experience Jesus and consequently to see and experience God. In his effort to see Jesus, the reader then becomes aware how saturated John is with the doctrine regarding the divinity ${ }^{2}$ of Jesus.

1. When reading the Gospel of John, the reader immediately becomes aware, already in the prologue, that the language and figures of style in John is different from those of the Synoptic gospels as well as the rest of the New Testament. John has a unique vocabulary, 'rich and profound, but above all distinctive' (Kysar [1976] 2007:8). In trying to describe this distinctiveness and difference in experience, the reader lacks vocabulary. Some of these striking differences will become evident in the investigation and reasoning of the topic.

2.Although the nouns $\theta \varepsilon$ ótnc ( $\mathrm{Col} 2: 9$ ) and $\theta \varepsilon$ เótnৎ ( $\mathrm{Rm} 1: 20)$ do not occur in John, this author has used the substantive 'divinity' to refer to Jesus' divine status or Jesus as deity as identified in John. There is no other way to do so.

Note: The collection entitled 'God as One', sub-edited by Erna Oliver (University of South Africa) and Willem Oliver (University of South Africa). 
This essay endeavours to look into how the early Christians experienced the divinity of Jesus as portrayed, in particular, in the Gospel of John, when they have read the gospel. The modus operandi will be, firstly, to discuss briefly how a reader becomes entangled in a text and, secondly, to focus on four distinguished mechanisms that, according to Waaijman and Iser, can foster spiritualities ${ }^{3}$ (lived experiences) when the text is read. These aspects are the dynamic interaction between the text and the reader, the creation of images, the dialectic of retention and pretension and, finally, the filling of gaps.

\section{The formation of new experiences}

According to Waaijman (2002:742), readers configure the presentation of sacred texts in their imagination. They accomplish this when they participate efficiently in the events in the texts. For Iser (1978:131), '[t]his involvement, or entanglement, is what places us in the "presentness" of the text and what makes the text into a presence for us'. This kind of participation in text denotes that the thoughtful reading of biblical texts can constitute several lived experiences, both of the text and the divine. ${ }^{4}$ The variety of spiritualities fostered by the reading of a text depends, firstly, on the content about the divine and, secondly, on who the reader is (Van der Merwe 2015:2-3).

People who read John for the first time or others who detect new truths after repetitively reading John can become entangled in the text. Firstly, new Christians are uncertain as to what happened and continue happening to them. Secondly, existing Christians are perhaps filled with excitement and desire to share the newly discovered truths with others - their new life in Jesus who transformed them; more about the divine identity of Jesus; or their adherence to his commandments in everyday life. In fact, they have become part or are already part of the household of God; what is now expected from them is to live devoted lives.

When reading (or studying) the text, the readers become involved in the text. Their presence in the text and their experiences of it depend upon their imagination and connotation with related and acquainted objects or events in their minds. When they experience themselves being involved in the events in the text, such as following Jesus, abiding in Jesus, living in the light or loving one another, then indeed something happens to them (cf. Iser 1978:131). Iser (1978:131) is convinced that if the 'present' reality and experience of the text are intense, the readers' characteristic selves, while reading, will draw them back into the 'past' to experience what the characters in the text experienced. If this happens, the Johannine text will then transfer the reader's established views into the past. This then becomes for the reader a present lived experience.

Such experiences are improbable if the readers adhere to their normal, personal views. 'Experiences do not come

3.In this article, the understanding of the use of the word 'spirituality' would refer to the 'lived experience of the divine'.

4.In this article, the word 'divine' is used when more than one of the three persons in the trinity is being referred to. about merely through the recognition of the familiar. Experiences only arise when the familiar is transcended or undermined' (Iser 1978:131). Hence, any new actions or acceptance of new truths will generate new experiences.

When a reader becomes entangled with a text, the effect is that the orientations of the reader are pressed into the past to suspend their validity for the moment of reading. The past of the readers then, irrespective of its content, starts 'to interact with the as yet unfamiliar presence of the text' (Iser 1978:132). These experiences are dynamic; therefore, they continue to change during the course of reading. This occurs because the realisation of any form of experience is not a matter of mathematics, but rather 'a restructuring of what the readers already possess' (Iser 1978:132) or even a redefining of what they believe.

When reading John, the characters (the disciples and those in dialogue with Jesus) and events in the text influence the reader. Something happens with the personal collection of the reader's experiences. Not a single experience in a text can remain unaffected because the existence of the experience has been influenced through the recognition of what the reader already knows. The acquainted experiences are only temporary; during the reading process, their significance changes. 'The higher the frequency of these moments, the clearer will be the interaction between the present text and the experience of the past event' (Iser 1978:132).

New experiences then emerge when the experiences that have been stored are restructured. Such restructuring is what provides to new experiences their amended forms (Van der Merwe 2015:8; cf. also Iser 1978:132). Hence, a new 'spirituality' emerges from a previous 'spirituality'; the divinity of Jesus will promote a new spirituality!

\section{Early Christian spirituality of the divinity of Jesus in the reading of the Johannine text}

\section{The dynamic interaction between text and reader}

In John, independent terminology and figures of style are applied to constitute different forms of speech ${ }^{5}$ to transport the reader into particular conceptual and experiential worlds. ${ }^{6}$ This subsection will only deal with three Johannine forms of speech to determine how the interaction between the text and the reader fosters 'lived experiences' of Jesus' divinity, namely, comparative speech, dualistic antithesis (dialectic language) and formulas of immanence. ${ }^{7}$ These distinguished forms of speech in John are utilised to

5.Goppelt (1982:II, 291-92) identified three forms of speech: dualistic antithesis, the 'I am' words and the designation of Jesus as Logos. This is certainly a narrowing of Johannine forms of speech. One can add the on $\mu \varepsilon \tilde{\alpha} \alpha$ forms of speech, comparative speech and formulas of immanence. John also has his own peculiar figures of style: irony, misunderstanding, symbolism (see Culpepper 1983:149-202); double meaning (Richard 1985:96-112). See also Schnelle (2001:354).

6.According to Iser (1978:107), a text is a 'structured prefigurement'.

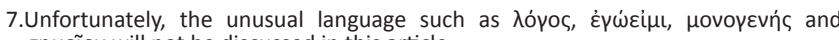
бп $\mu$ ĩov will not be discussed in this article. 
investigate how the reader is drawn into the text in order to experience (believe) Jesus as the Christ, the Son of God. Each of these forms of speech occur quite frequently throughout John.

According to Iser, the text only achieves an effect during the reading of the text to provide meaning and experience of the text. 'Thus the meaning of a literary text is not a definable entity but, if anything, a dynamic happening' (Iser 1978:22). The understanding (and interpretation) of a text necessitates continuous dialogical negotiation between the text and the reader (cf. Iser 1978:107). The frequent occurrences of the distinguished forms of speech and the spiral presentation of themes in John facilitate this dialogical negotiation of meaning. Such negotiations evoke different 'spiritualities'.

\section{Comparative language}

This subsection focuses on how John is saturated with Torah spirituality (see Van der Merwe 2014:1-9), where he compares Jesus with probably the most important and influential Old Testament character, Moses (Jn 1:17, 45; 3:14; 4:45; 5:46; 6:32; $7: 19,22,23 ; 8: 5 ; 9: 28,29) .{ }^{8}$ Already in the Prologue (Jn 1:17), Jesus is associated and compared with Moses:

'The law indeed was given through Moses; grace and truth came through Jesus Christ'. ${ }^{9}$

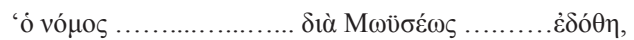

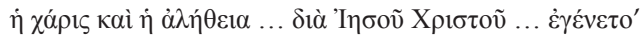

In this antithetical parallelism, John contrasts Jesus with Moses. For him Jesus is the eschatological fulfilment of all that Moses represented. One main theme that occurs throughout the Torah is that of divine presence (Ex 33:15-16, 34:9). God accompanies the Israelites during their travelling through the desert.

They lived in tents. Moses, ordered by God, built a tent to be the dwelling place of God during their wandering through the desert (Ex 36:8-19). On completion, God took possession of this tent: 'Then the cloud covered the tent of meeting, and the glory of the Lord filled the tabernacle' (Ex 40:34; Boismard 1993:94-95). Moses kept the tablets of the covenant in the tent but was not permitted to enter the tabernacle after the cloud settled upon it. The glory of the Lord covered the tabernacle (Boismard 1993:95) and this consequently fostered lived experiences of the presence of God among the Israelites (cf. Ex 33:14, 15, 40:34, 35).

\footnotetext{
8.The following texts substantiate in John the motif that Jesus is greater than. The Samaritan woman refers to Jesus as, 'Are you greater than our ancestor Jacob ... (Jn 4:12). In 5:20, Jesus said to the Jews who accused him of working on the Sabbath that the Father will show him 'greater works than these, so that you will be astonished'. In 5:36, Jesus said: 'But I have a testimony greater than John's. In 8:53, the Jews asked Jesus, 'Are you greater than our father Abraham, who died? The prophets also died. Who do you claim to be?' In 10:29, Jesus said with regard to the eternal life he has given his followers, 'What my Father has given me is greater than all else, and no one can snatch it out of the Father's hand'. When Jesus talked to his disciples about his death, he said that, 'No one has greater love than this, to lay down one's life for one's friends'.

9.No direct citation from Deuteronomy 18:18-19, 'I will raise up for them a prophet ..., occurs in John. The theme of 'Jesus as the new Moses' is evident and conjured by the title, Prophet, allocated to Jesus (see Jn 4:19, 44; 6:14; 7:40; 9:17; see also In 7:52; Van der Merwe 2014:4). See Boismard (1993:1-68) for a more comprehensive discussion of 'Jesus, the Prophet like Moses'.
}

John explains a new manner through which God becomes present in a new period in Israel's history via a new intermediary: 'And the Word became flesh and lived among $u s^{\prime}$ (Jn 1:14). By using the personal pronoun ( $\dot{\varepsilon} v \dot{\eta} \mu \mathrm{i} v$, Jn 1:14), John draws the reader into the text to experience this event. The prologue explicitly says that the Word is God. This implies that God incarnates to reside with

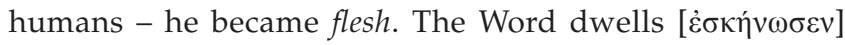
among humans as God [Yahweh] dwelt among the Israelites in the desert (Boismard 1993:95-96).

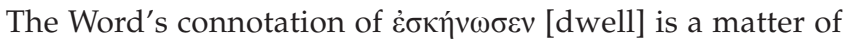
presence. God is present through Jesus similarly as through the tabernacle and the cloud (Van der Merwe 2014:5). In this comparison between Jesus and Moses, the readers of John experienced the awareness of God's presence and the content of 'their salvation through Jesus Christ ( $\lambda$ óros and

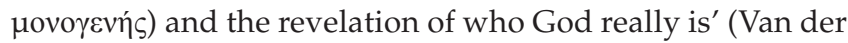
Merwe 2014:6).

The above argument clarifies why the lived experiences of the resurrected Christ, among the early Christians, led to Jesus' veneration. 'Both the experiences and veneration contributed to the reformulation or reconfiguring of religious convictions regarding the Torah and Jesus who is

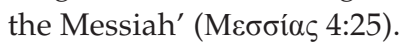

The spirituality experienced when reading the Torah is renewed and redefined in Christ. For the reader God is now to be found only in Jesus (Van der Merwe 2014:4) who is the Christ, the Son of God (cf. Jn 20:31). The old order (Torah) is substituted by a new order (Jesus) with a new centre (Casselli 1997:37; Van der Merwe 2014:4). In his comparison of Jesus with Moses (Torah), John succeeds in pointing out the divinity of Jesus.

Through the repetitive comparison of Jesus with Moses, John convinces the reader about Jesus' divinity in order for the reader to identify with Jesus.

\section{Dialectic language - The Johannine dualism}

Dialectic vocabulary occurs throughout John and has a great influence on the reader. References to Jesus as the one who has come from above ${ }^{\prime 10}$ and the one who has come' ${ }^{\prime 11}$ echo regularly. This motif is discussed frequently in the first part of John (1-12) which is evident particularly in Chapter 6. In this discourse, Jesus contrasts the $\mu$ óvv $\alpha$ with heavenly bread, based on the reality that he is 'the true bread that came down from heaven' (Jn 6:50). In certain discourses, it receives central attention (see Jn 7:27ff.; 8:14ff.; 8:42ff.). Probably the most prominent text comes from the prologue. ${ }^{12}$

10.A few texts that designate this fact are $3: 13 ; 6: 33,38,41,42,50,51,58 ; 7: 28$ $8: 14,42$.

11.Texts designating this fact are $1: 9,11 ; 3: 19 ; 5: 24,43 ; 10: 10 ; 12: 13,27,46,47 ; 15: 22$ $16: 28 ; 18: 37$; see also $6: 14 ; 4: 25 ; 7: 27,31 ; 11: 27$

12.The prologue already provides a 'theological foundation' (Waldstein 1990:312) for

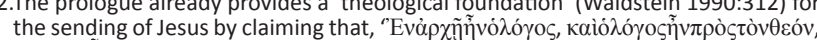

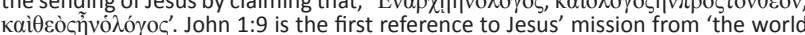

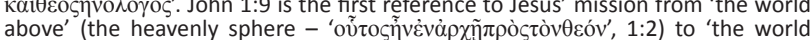

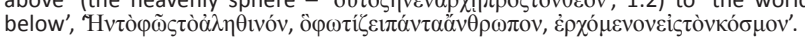


Multiple references of Jesus' return to the Father occur equally repeatedly in John, more frequently in the second half, closer to the time of his crucifixion, in his discourses with his disciples (Jn 6:62, 7:33, 35; 8:14, 21, 22; 13:3, 33, 36; $14: 2,4,5,12,28 ; 16: 5,7,10,17,28 ; 17: 11,13 ; 20: 17)$. The descent of Jesus is clearly linked with his ascent to the Father (cf. Jn 3:13; 8:14; 13:3; Van der Merwe 1996:135). John uses a variety of language patterns ${ }^{13}$ to emphasise the movement between heaven and earth and the qualitative difference between the 'above' and the 'below' to draw the readers to experience this dualism (this 'difference') in the text.

Wayne Meeks published an excellent and provocative study on the importance of this motif. This publication starts with reference to the importance of this pattern (Meeks 1972):

The uniqueness of the Fourth Gospel in early Christian literature consists above all in the special patterns of language, which it uses to describe Jesus Christ. Fundamental among these patterns is the description of Jesus as the one who has descended from heaven and, at the end of his mission, which constitutes a krisis for the whole world, reascends to the Father. (p. 141)

\section{Meeks (1972) is of the opinion that:}

The pattern, descent and ascent, becomes the cipher for Jesus' unique self-knowledge as well as for his foreignness to the men of this world ... The descent and ascent of the Son of Man thus becomes not only the key to his identity and identification, but the primary content of his esoteric knowledge, which distinguishes him from the men who belong to 'this world'. (p. 154)

An important theological aspect regarding the mission ${ }^{14}$ of Jesus is that he came from the 'above' into the 'below' to live

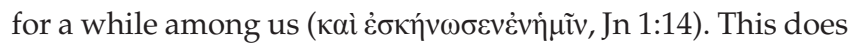
not connote that he became part of the 'below' (Jn 17:16). In fact, he made the 'above' present in the 'below' (Jn 1:14, 17). The mission of Jesus brings about a possible tangible contact between these two 'realities'. The 'above' comes in an audible, sensible and experiential sense to exist in the 'below'. Van der Watt (1991:108f) states that this contact makes interaction between these two realities likely. This concrete contact is best formulated in John 1:14: 'And the Word became flesh and lived among us, and we have seen his glory, the glory as of a father's only son, full of grace and truth'. In Jesus, God thus came to dwell among humans. The agency concept depicts both the role and the function of the Son of God and also the relationship of the Son with his Father that prevails throughout his mission (cf. Nicholson 1983:21).

\footnotetext{
13.John uses various 'language patterns': (1) word-couples in dualistic form ( $\alpha$ vo $\alpha$ aiv

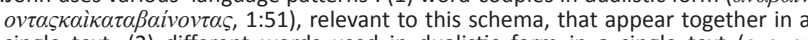
single text; (2) different words used in dualistic form in a single text $(\rho \chi 0 \mu \alpha$

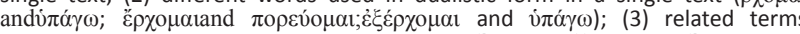

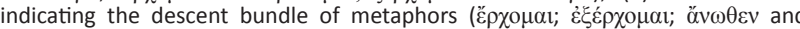

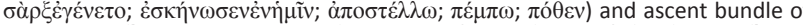

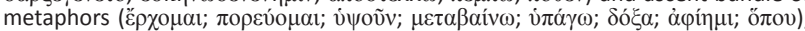
(4) finally, one case where the descent and ascent are implied in the single verb,

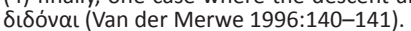

14. In discussing the movement of Jesus from the above to the below and from the below to the above, scholars use different terms and motifs such as send (Kuhl 1967; Waldstein 1990:311), mission (Ashton 1991:308), descent-ascent (Meeks 1986:141ff; Nicholson 1983:21; Pryor 1991:341ff) and agency (Ashton 1991:312; 1986:141ff; Nicholson 1983:21; Pryor 1991:341ff) and agency (Ashton 1991:312; der Watt 1991:108ff.). See Waldstein (1990:312) and Mercer (1992:457) for lists of der Watt 1991:108ff.). See Walds
literature on 'sending' in John.
}

John also extends this dualism of movement to the contrast between two worlds: a world above and a world below. Jesus said to the Jews when he argued with them, 'You are from below, I am from above; you are of this world, I am not of this world' (Jn 8:23). In John, 'this world' converses with the 'world above'. This world is evil and the devil is its ruler (Jn 16:11; cf. Jn 8:44). The Son of God (Jesus) was sent by God (Jn 3:16) to be the light of this world $(8: 12 ; 11: 9)$. Within the context of the spatial contrast, a qualitative contrast, ${ }^{15}$ in human perspective, became clearer and more concrete. ${ }^{16}$ The readers are caught up in this dualism in their experiences of the pairs of opposites that occur throughout John: light versus darkness (Jn 1:5); spirit versus flesh (Jn 3:6); God versus Satan (Jn 3:27); heaven versus earth (Jn 3:31); life versus death (Jn 3:36); above versus below (Jn 8:23); truth versus falsehood (Jn 8:44-47). After the completion of his mission in this world, he must return to the world he came from (Jn 3:13; 6:38; see also Jn 6:62; 20:17; Ladd 1993:223-224).

When reading through the gospel, the dialectic language indicated above creates tension within readers. This forces readers to restructure their belief system. When they hear and experience Jesus speaking to a crowd or to someone, this experience induces introspection. The reader compares and associates continuously within this dualistic environment. In this dialectic vocabulary (of movement, locality and pairs of opposites) the reader experiences the divine 'Otherness' of Jesus. The readers are constantly put before a choice. They are compelled to make a choice. They have to move to a spiritual level to perceive Jesus' identity (his descent and ascent are closely connected). The reader cannot understand the descent without incorporating Jesus' ascent, and the other way round. The theological structure of the descentascent serves to reveal the Son and the Father from the 'world above', in the 'world below' (Van der Merwe 1996:247-248).

It seems as if the entire system of religious thought in John finds itself caught up within this dualistic framework. This facilitates their conception of Jesus' movement between the 'above' and the 'below' and consequently casts more light on the identity of Jesus: he is originally from another world, the world above! This provides a new impetus to a new spirituality, both independent of the Torah, and as experiential as the one above, now below, to place the reader in the above.

\section{Formulas of immanence}

Another feature in the rhetoric of John that fosters 'lived experiences' of Jesus' divinity is the multiple 'formulas of

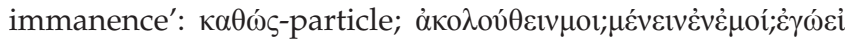

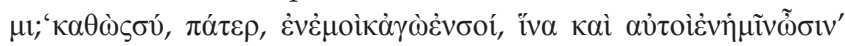

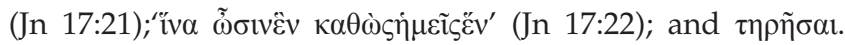
Only four will briefly be discussed.

15. Numerous interpreters comment on the Johannine contrasts; cf. Bultmann (1953:361ff.), Brown (1975:CXV), Ladd (1977:223ff.), Van der Watt (1991:106ff.), Ashton (1991:205) and Kysar (1975:131; 1993:58ff.)

16.While John utilises much dualistic terminology, it should not be interpreted as the reflection of an ontological dualism (Mercer 1990:459). Light and darkness are not two equal powers. The world, although associated with darkness and evil, remains two equal powers. The world, although associated with darkness and evil, remains
the creation of God (Jn $1: 10)$ and the object of his love (Jn 3:16) and salvation (Jn 3:17; 12:47; Sanders \& Mastin 1975:938). 
The $\kappa \boldsymbol{\alpha} \theta \omega \varsigma$-conjunction of comparison: This conjunction ('just as') occurs frequently in John in uniting God-Jesusdisciples in relationships. It defines the union (Radl 1991):

'[B] etween Father and Son $(5: 30 ; 8: 28 ; 12: 50 ; 14: 31 ; 17: 2$; also cf. 5:17-26), between Jesus and his disciples (13:15, 34; 15:12; $17: 14,16)$, and the union involving both relationships (6:57; 10:15; 14:20; 15:9, 10; 17:11, 18, 21, 22; 20:21; cf. 17:23)' (p. 226).

When Jesus' followers (characters in the text or readers) adhere to the gist of their relationship with Jesus, they will experience something of his divinity because of this immanence and his association and comparison with the Father (Van der Merwe 2017:5), for example:

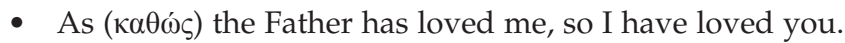
(Jn 15:9)

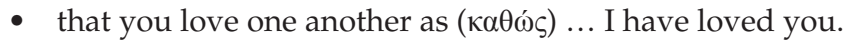
(Jn 15:12)

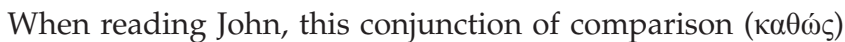
assists the reader in associating with Jesus and consequently becoming attached to Jesus to experience the divine life, divine mission, divine dependence, divine love, divine unity and divine glorification. ${ }^{17}$ Some of the $\kappa \alpha \theta \omega \dot{s}$-particles (Jn 5:30; $8: 28 ; 12: 50 ; 14: 31 ; 17: 2$; also cf. Jn 5:17-26) create in Jesus a divine mirror image. In Jesus' application of this particle in the divine sphere (Father and Son), the reader becomes aware of the many facets of the divine identity, in particular the divine identity of Jesus. When the reader imagines all these facets and is drawn into the text with the multiple personal pronouns when Jesus applies these facets to his disciples, the reader experiences the different divine facets of Jesus' identity. What is left is for the reader to apply these experiences of the divine to a spiritual life of imitatio Christi.

Following Jesus: The fact that so many people followed Jesus, without him even requesting them to do so (except Jn 1:43) (Jn 1:43; 8:12; 10:4, 5, 27; 12:26; 13:36-38;21:19-23), immediately draws the reader into the text events for participation. This comprises theologically a 'God-ward movement' and practically it involves being with Jesus (Jn 1:39), being led by Jesus and being obedient to his commandments (cf. Kim 2017:225). Following Jesus was not only a physical accompanying. The motif behind following Jesus was to experience enduring communion with him (Kim 2017:226).

Following Jesus entails being guided by him. In John 12:26,

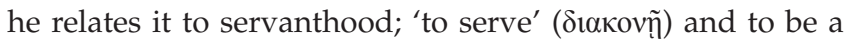

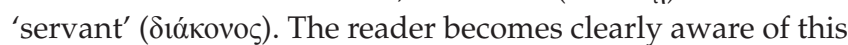
point: 'following him entails to serve him as his servants' (Kim 2017:226). John portrays Jesus himself as the complete servant of God. He accomplishes everything God instructed him to do (Jn 5:36; 10:18; 14:31; 15:10; 17:4) and lives in concurrence with the will of the one who has sent him (Jn 5:34; 5:30; 6:38; 8:29). Only those following him until the

17.In John the $\kappa a \theta \omega c$ concept occurs in the following texts: 'dependence $(5: 19 ; 6: 57$ 15:5; also cf. $12: 49 ; 14: 10 ; 15: 15 ; 17: 8)$, mission $(13: 20 ; 17: 18 ; 20: 21)$, knowledge (10:14, 15), love in obedience (13:34f; 15:9; 15:10; 15:12; 17:23; also cf. $5: 20$

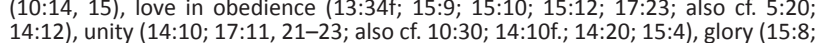
$14: 12)$, unity (14:10; 17:11, 21-23; also cf. 10:30; 14:10f.; $14: 2$
$17: 1-5 ; 22-24)$ and life (6:57)' (Van der Merwe 2001:139). end will experience his divine presence; will be where he is. Their obedience will enable them to see and experience his glory (Jn 17:2418; cf. Kim 2017:227). Consequently, the reader becomes aware that the following of Jesus and being with him 'includes both going down with Jesus to the cross and going up with him to the presence of the "holy" Father' (cf. Kim 2017:227). This is what prescribes a servant's 'participation' when following Jesus along his journey and making that journey his or her own.

Jesus calls on his disciples 'to abide in me': The verb $\mu \varepsilon ́ v \omega$ [abide] ${ }^{19}$ is used 29 times (Jn 1:33, 38, 39; 3:36; 4:27; 5:38; 6:27, 56; 7:13; 8:35(2×); 9:41; 12:24, 34, 42; 14:10, 17, 25; 15:4(2×), 5, $6,10(2 \times), 16 ; 20: 5 ; 21: 4,22,23)$ in John. Nine of them appear in chapter 15:4-12, which is relevant for this research. The disciples are called by Jesus to abide in him and he in them, for them to bear much fruit later. In these verses, the personal pronoun $\sigma u ́$ [you] occurs 18 times and the reciprocal pronoun $\dot{\alpha} \lambda \lambda \dot{n} \lambda$ ovs (one another, Jn 15:12) only once. This high frequency of occurrence prompts the readers to associate with the disciples and share in the events depicted in the text. When readers associate with Jesus, he becomes a present reality for them. The text refers to a mutual abidance between Jesus and his followers, which is realised when they obey his commandments (word) (cf. Ridderbos 1997:517). This is evident in John's usage of the imperative, $\mu$ civ $\alpha \tau \varepsilon$ (Jn 15:4, 9), and the participle, ó $\mu \varepsilon \dot{v} \omega v$ (whoever abides Jn 15:9). This usage may be regarded as conditional, to the 'bearing of much fruit'. This is critically necessary and is part of the en route to the lived experience of Jesus (Van der Merwe 2017:8).

What does it mean to 'abide in him'? It is helpful to look at the

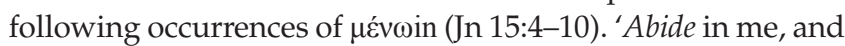
I in you' (Jn 15:4); 'As the branch cannot bear fruit by itself, unless it abides in the vine, neither can you, unless you abide in me' (Jn 15:4); 'Whoever abides in me and I in him, he it is that bears much fruit, ...' (Jn 15:5); 'If anyone does not abide in me ...' (Jn 15:6); 'If you abide in me, and my words abide in you, ask whatever you wish, and it will be done for you' (Jn 1:7); 'As the Father has loved me, so have I loved you. Abide in my love' (Jn 15:9); 'If you keep my commandments, you will abide in my love, just as I have kept my Father's commandments and abide in his love' (Jn 15:10); 'This is my commandment, that you love one another as I have loved you' (Jn 15:12).

For the readers, verses 9 and 12 carry the key what it entails to abide in Jesus and to experience him. The readers become aware of Jesus' love for the Father and for them especially through the references to Jesus obeying the will of God, which culminates in his crucifixion. To abide in his love means to continue having fellowship with him, to love (and obey) him, even as he loves the Father (15:10). BeasleyMurray (1999:272) is correct in connoting that ' $\mu$ civa [aorist tense], could signify "Step into union with me"

18.'Father, I desire that those also, whom you have given me, may be with me where I am, to see my glory, which you have given me because you loved me before the foundation of the world'.

19.Other closely related formulas of immanence occur in John 17:20-23: ' $\sigma 0 ́, \pi \alpha ́ \tau \varepsilon \rho$,

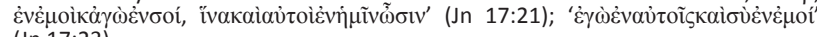
(Jn 17:23). 
(also cf. Peterson 2013:24). The mutual indwelling as described in John 15 characterises the mystical union between God, Jesus and those who follow him (cf. Stander 2017:166; Van der Merwe 2017:9).

Jesus obedient to the father: Jesus' intention was always to

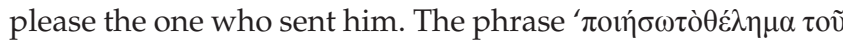
$\pi \varepsilon \dot{\varepsilon} \mu \alpha \alpha \tau$ ó $\varsigma \mu \varepsilon^{\prime}$ is one of the key ideas in the structure of John (Lindars 1981:194) and occurs in 4:34, 5:30, 6:38 and by implication in 7:18; 8:50. ${ }^{20}$ In John 8:29 $\tau$ ò $\theta \dot{\varepsilon} \lambda \eta \mu \alpha$ was

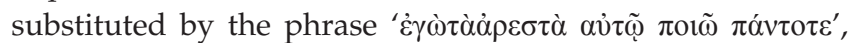
but the intention remained unchanged. This technique marks these sayings as a word of revelation.

Jesus' whole life is based on and centres on his endeavour to

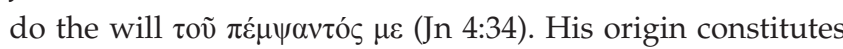
the heart of this attitude (Jn 6:38). Every time Jesus speaks

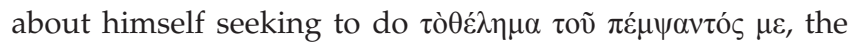

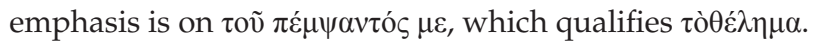

The unity between the Father and the Son, expressed through

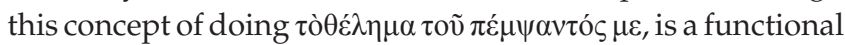
and moral unity (cf. Jn 10:30; cf. Lindars 1981:194) that implies an ontological unity. Morally, it is the complete obedience of Jesus to the will of the Father, which justifies the exclusive claim of Jesus to be committed to the Father (cf. Jn 3:16-21, 31-36). His obedience towards God dominates his whole life and culminates in the cross. ${ }^{21}$ His whole life centres on and

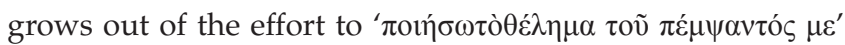
(Schnackenburg 1965:480). This attitude (see also Jn 5:30; 6:38-40) is intended to describe the revelation through Jesus as an action of God (Van der Merwe 1996:36).

These indications of Jesus' submission to the Father's will should not lead to an interpretation that reduces Jesus' identity to his role as an ordinary agent of the Father. Jesus states clearly that he is not concerned about his own will (Jn 5:30; 6:38) but is interested only in doing the will of the one who sent him.

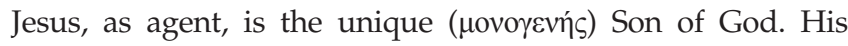
mission is rooted in something deeper than a mere commissioning at a historical moment (see Jn 10:36); it stems from the fact that he is the 'Son of God'; $; 2$ in fact, he is God (Jn 1:1; 20:28). This obedience reveals his unity with the Father. Throughout his mission, he experiences the presence of his

20.The expression "to do the will of God" frequently occurs as a concept in the Oid Testament, Judaism and primitive Christianity. In John, it is frequently combined

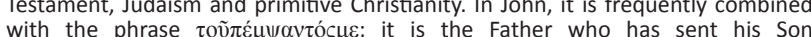
with the phrase $\tau$ ov $\pi \varepsilon \mu \psi$
(Schnackenburg 1965:480).

21.A theology of the cross can be construed from many Johannine texts that poin firmly to an orientation thereof (see Jn 1:29, 36; 2:14-22; 3:14-16; 10:15, 17-18 $11: 51-52 ; 12: 27-32 ; 19: 30)$. The placement of the following events demonstrates that the revelation of Jesus and the glorification of the Son of Man culminates a the cross; the cleansing of the temple early in the gospel, the orientation of the foot washing (Jn 13:1-3, 18-19) and Jesus' last words on the cross in John (19:30) point towards a theology of the cross. For John the cross is the objective of Jesus mission and the place of redemption. Jesus' dignity culminates at the cross when he is 'lifted up' and glorified (see Jn 12:27-33). The incarnation and cross are the he is lifted up and glorified (see In 12:27-33). The incarnation and cross are the centre of Johannine Christology (Schnelle 2001:357). For Keener ([2003] culmination is also evident from John 17:1-5 (his glorification) and on the cross when Jesus said, $\tau \varepsilon \tau \varepsilon \dot{\lambda} \lambda \varepsilon \sigma \tau \alpha \mathrm{l}$ (Jn 19:30).

22.It will later become apparent that the commission of the disciples is also rooted in the fact and the historical event that they are children of God (Jn 1:12); part of the family of God.
Father in him, which enables him to fulfil the will of the Father in obedience (Van der Merwe 1996:322). Jesus' obedience to

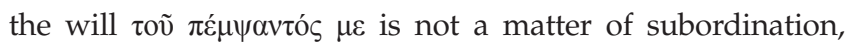
rather of a divine 'bosom' (Jn 1:18) unity. Jesus cannot act differently, he will obey because he is as the Father divine.

When Jesus' followers obey his commandments (word), they in fact obey the will of 'Him who sent me', for Jesus lived according to the will $\tau$ ov $\pi \varepsilon \dot{\varepsilon} \mu \psi \alpha v \tau$ ó $\varsigma \varepsilon$ (Jn 4:34; 5:30; 6:38; 8:29) ${ }^{23}$ (Van der Merwe 1996:453). Jesus's references here to

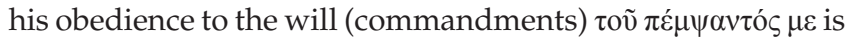
not to serve as an example, rather as a comparison ( $\kappa \alpha \theta \omega \varsigma)$ for his disciples (and the readers) to imitate him. The readers realise that through their obedience to Jesus' commandments, they will experience his presence as he experienced the presence $\tau$ oṽ $\pi \varepsilon ́ \mu \psi \alpha v \tau$ ó $\varsigma \mu \varepsilon$. As the behaviour of Jesus manifests the will of the Father (Jn 4:34; 6:38; Van der Merwe 2017:9), so will their obedience be the manifestation of Jesus.

\section{The creation of images}

Iser points out that in the reading of a text, readers also experience the physical characters, images, material objects, attitudes or events, described in the text, in their minds. Through this, the text and the readers are connected; the readers themselves, '... in constituting the meaning, ${ }^{24}$ is also constituted' (Iser 1978:150). As the reading continues, a sequence of the present images is constituted in the minds of the readers. The consecutive images subsequently 'progressively constitute a certain configuration to generate both a field of meaning and experience' (Iser 1978:108-118). ${ }^{25}$ This is exactly what happens in John. Family metaphoric is applied to the text to generate the configuration of the familia Dei. This consequently generates a new field of meaning and experience. Such a configuration of images then causes understanding, interpretation and experience, later to result in the application thereof in the lives of the readers (Van der Merwe 2015:6).

The symbols and metaphors in John absolutely stimulate emotions $^{26}$ and prompt feelings to create an exciting Johannine narrative. For the readers this would foster more effectively spiritual experiences, for example, when Jesus referred to himself as the bread of life at the shore of the Sea of Galilee (Jn 6:1-67). This metaphorical statement generated both negative (Jn 6:60) and positive emotions (Jn 6:68-69; Albalaa 2019:139; Barton 1996:571-591).

23.In these four texts, Jesus refers to the will of 'him who sent me' and not the will of 'God' or the 'Father'. Then, in the following three texts, (Jn 5:30; 6:38; 8:29), he combines the 'him who sent me' with the 'Father'.

24.Schneiders (1982:59) is of the opinion that total reader involvement (cognitive and affective engagement) in a text is necessary to find meaning (and gestalt) in some literary genres. For her then, 'a literary genre is a tool for total reader involvement with the subject matter of the text' (Schneiders 1982:60). For Iser (1978:275), the meaning of a written text is constituted the moment when the text and the reade connect. For Thompson (2000:204), such a connection brings the literary work into existence. Meaning, then, is found only when '... the imaginative activity of the reader seeks to create coherence while reading progressively through the imaginatively-composed biblical text' (Thompson 2000:204).

25.See also Robbins (2008:1-26) on his discussion and explanation of rhetography and rhetology.

26.See Barton (1996:571-591) for a more thorough discussion on emotions in Early Christianity. 
John succeeds in his rhetoric to generate a linguistic-textual world that addresses the concerns and desires of the community, as well as the composition of images in the minds of the readers when they read the text.

Surely, valid reasons and persuasive explanations can be offered for the decision of scholars to select the familia Dei expression in their arguments and research to explain the coherence and sense of the family metaphors in John. Some explanations can be drawn from the similarities between the metaphoric entities of the group (in general) and family (in particular) (cf. Albalaa 2019:158).

John uses symbols and metaphors as a special mode for perception, to make it possible for the unseen Father, the divinity of Jesus and certain aspects of life in the familia Dei to be revealed and to be conveyed to the Johannine readers. Johannine symbols and metaphors ${ }^{27}$ are therefore a figurative way through which a divine reality is depicted in terms that are more generally associated with another reality (familia Dei), which correlates with it through analogy. Johannine symbols and metaphors are loaded with biblical-theological content. Jesus used these symbols and metaphors to disclose his divine character and identity, the eschatological dimension of his deeds and to reveal his Father. Therefore, John uses literary devices, in particular, certain symbols and metaphors to provide conceivable and suitable data to apprehend modes of divine experiences from the perspective of the familia $\mathrm{Dei}^{28}$ (Albalaa 2019:177).

With reference to John's gospel, it is clear that the familia Dei is not merely an isolated Johannine element or metaphorical stylistic device. Rather, this is both an essential constituent of the figurative language of John and a powerful motif to express his theology. It is a significant subject that opens up the Johannine narrative, employing family metaphoric to introduce the eternal Logos, 'Who was with God and was God in the beginning' (Jn 1:1), and to portray the mystery of his incarnation (Jn 1:14). The first fruits of this mystery are found in Jesus, giving to those who accept (believe) him 'the power to become children of God' (Jn 1:12), and making 'the Father known' (Jn 1:18) to all. These fruits are fundamental components of the Johannine experience of both Jesus and God and constitute a motivation and modus operandi for the new member of the familia Dei, namely, the early Christian.

When reading John, the readers discover that God is uniquely the Father of the Son (Jesus, Jn 1:18; 10:36).

Most of the statements about God as Father include the role and identity of the Son, and vice versa. To speak of the Father is to speak of the Son; to speak of the Son entails speaking of the Father (Thompson 2014:155). God then is especially

27.Van der Watt (2000:22) states that metaphors in the Fourth Gospel both describe and create'. According to Jordan (1974:235-236) 'metaphor does not create and create. According to Jordan (1974:235-236), 'metaphor does not create reality, but aims to describe this reality. Avis (1999:102) argues that ' $m$ m]etaphors participate in the reality that they seek to convey'.
the capacity to foster an experience of the divine.

28.Albalaa refers to Bultmann (1973:16), Johnson (1993:28) and Strecker (1996:25) who comment on the metaphorical statement of God's nature in relation to his children. known in relationship to Jesus, as God is depicted as the Father and Jesus as the Son (Juel 1997:317). Probably, the most fundamental verse in John to identify and characterise the Father and the Son comes from verse 5:26, ${ }^{29}$ which states that 'For just as the Father has life in himself, so he has granted the Son also to have life in himself' (cf. Thompson 1999:21). ${ }^{30}$ The Father (as an earthly father) is the source of life. Because the Word (the Son), distinctive of God, has that 'life in himself' (cf. 1:4; 5:26), the Word therefore is called God (1:1). The life that the Son shares with the Father and the Holy Spirit is granted to the members of the familia Dei.

By the reception of this life, rebirth takes place to elevate the readers to the realm of the familia Dei. John explains this knowledgeably and competently to his readers utilising symbols and metaphors. He then entwined these figurative devices with the form, style and mode of the revelatory language of John. Mutually, they constitute a literary context for the familia Dei metaphor in the Johannine narrative. They fostered images and lived experiences of the trinity in the minds of readers, which powerfully influence and transform the readers (cf. Albalaa 2019:167). ${ }^{31}$

\section{The dialectic of retention and pretension}

Any form of reading prompts readers to become more attentive and active. In descriptive texts, the imagination of the reader will arouse images of the text. These images arise and develop against the background of what 'has already been read and what still remains to be read' (Waaijman 2002:744). Husserl (cited in Waaijman 2002:744) labels the recalled background 'retention' and the expected background 'pretension' (see also Iser 1978:112). Retention encompasses what has already been read, and pretension the text still to be read. 'The tension created between retention and pretension controls the reading experience' (Van der Merwe 2015:7; see also Waaijman 2002:744). During the reading process, the text continually discloses itself at every moment of reading and consequently fosters various lived experiences. The text then unfolds against 'the combined background of memory and expectation' (Van der Merwe 2015:7; Waaijman 2002:744).

The best application of this mechanism is to focus, on a theological level, on the different titles John uses to talk about Jesus. They occur arbitrarily throughout John and influence

29.'For as the Father has life in Himself, so He has granted the Son to have life in Himself' (Jn 5:26).

30.The noun 'Father' often appears alone. In one instance, the adjective 'holy' (Jn 17:11) is added and quite often the personal pronoun 'my' (see, e.g., Jn 5:17). A few times the phrase 'who sent me' (see, e.g., In 5:37) is added and once the adjective 'living (Jn 6:57) is added. God is 'the living Father'. This phrase ('the living Father') reflects the fundamental designation of God as 'the living God' (Thompson 1999:21).

31.Shibles (1972:28) defines metaphor as 'the instinctive and necessary act of the mind exploring reality and ordering experience by which the unknown is assimilated to the known'. Metaphor, generally spoken, suggests experience beyond the ordinary literal sense of everyday life (cf. MacCormac 1976:83; Albalaa 2019:169). Shibles (1972:31) suggests that 'metaphors motivate the imagination of the readers and excite in them a heightened awareness of qualities called spiritual'. the readers and excite in them a heightened awareness of qualities called spiritual' MacCormac (1976:X, xviii) resonates Shibles' suggestion that 'metaphors have an emotional and spiritual effect upon the readers' (cf. Albalaa 2019:170). Metaphors, therefore, can assist to create new meanings and new perspectives. At an individua evel, metaphors are used to describe the unknown (the divine) in terms of the known (family metaphorics). This implies that metaphor is used to construct meaning. Familia Dei then is the sphere in which fellowship is constituted and the divinity of Jesus experienced (cf. Van der Merwe 2009:89-90). 
the understanding of one another. Readers, through the retention and pretension of a title, create a profile of each title that influences not only their understanding of that title in a particular text but also casts light on the understanding of the other titles allocated to Jesus in John.

On the theological level, John is perceived as a coherent text. ${ }^{32}$ Van der Watt (1991:93-126, see also Neyrey 2007) made a valuable contribution regarding the structural exposition of Johannine theology (see also Loader 1984:188-216), which he postulates as a 'pictorial representation'. He expounds the Johannine thought system ${ }^{33}$ as organic-systematic in character. Therefore, it can be interpreted to be pictorially presented. The various themes (in this essay titles) are progressively connected and evoke one another systematically because of their multiple occurrences throughout John (Van der Merwe 1996:4). ${ }^{34}$ Although the movement of thought 'circles' around particular concepts, they continue to move forward, while persisting within a circle.

John repeatedly assigned various titles (and names) to Jesus in order to portray, from different angles and perspectives, his divinity and divine involvement. All these names and titles complement and enrich one another to assist the reader's imagination to experience Jesus as divine from different intelligible perspectives. They are linked organically and recall one another systematically in the reading process.

In a very recent publication, White (2018:52) discusses the meaning of names in antiquity. She points out that names (and of course titles) touch the quintessence of personality; they invite the reader into the distinctiveness of the person. Names are more than descriptive labels. They have their own dynamism so that when pronounced or read, it brings the named person into the mind and imagination. A name carries personal identity and it declares the uniqueness of the person. Names differentiate and distinguish. Names enable communication with other entities (people, Jesus and God), for example, speaking to God directly, speaking about God, appealing to God and remembering God. Through names the strangeness or the unknownness of a person becomes conversant and recognisable. To designate different names and titles to Jesus is to acknowledge his existence and characterise his identity (cf. White 2018:53).

Middle Eastern countries in antiquity paid great attention to the symbolic meaning of names. For them, names conveyed 'something of the experience or character of a person' (White 2018:55). The Old Testament clearly reflects this concern for symbolic meaning. Names were given to characters that reflected some kind of connotation or described something in their lives. The name of Abraham's nephew, Lot, means

32.'Each part of a text, down to its individual sentences, must be understood from the perspective of the whole and as constituent parts thereof. The key to understanding particular texts lies in the intratextual world of the entire Gospel' (Schnelle 2001:353).

33.Van der Watt refers here to the different loci in systematic theology.

34.The perception of Meeks (1986:161), although earlier, supports the hypothesis of Van der Watt when he writes, 'The reader cannot understand any part of the Fourth Gospel until he understands the whole'. 'covering' or 'veil'. God instructed him before the destruction of Sodom to 'cover' his eyes. He had to escape from Sodom without looking back. Pharaoh's daughter called the Hebrew boy who she saved from death in the Nile, Moses, which means 'pulled out of the water'. Aaron means 'lofty', 'elevated'. As the brother of Moses and the first high priest of the Israelites, this name was appropriate (White 2018:55). ${ }^{35}$ Samuel means 'name of God' or 'God has heard'.

In the New Testament, there is a similar symbolic significance of names. John was not a family name for the Baptist. The name means, 'God has been gracious, has shown favour'. His parents, Zachariah and Elizabeth, gave him this name ${ }^{36}$ because they wanted the name of their son to echo the miraculous nature of his birth (Lk 1:57-66), as Elizabeth was an old woman, past childbearing age. Simon, one of Jesus' disciples, was given a new name by Jesus. Jesus named him Peter, which means 'rock', and this symbolises his foundational role in the Church. The most significant name of all in the New Testament was the name Jesus. 'And now, you will conceive in your womb and bear a son', said Gabriel to Mary, 'and you will name him Jesus' [saviour] (Lk 1:31; cf. Lk 2:21). This name should stress the mission of the Messiah (White 2018:56). ${ }^{37}$ Each of the many names and titles of Jesus describes a different aspect of his multi-faceted character. This article will focus solely on the following four titles of Jesus in John, namely, Logos, Messiah, Son (of God) and Son of Man. ${ }^{38}$ These titles complement one another. Except for 'Logos', the other three titles occur most frequently throughout John. The retention and pretension of Jesus' titles will enable the reader to construct meaningful profiles of these titles in order to characterise Jesus' divinity.

\section{Logos (pre-existence)}

John designated Jesus four times in the prologue to be the Logos: 'In the beginning was the Logos, and the Logos was with God, and the Logos was God' (Jn 1:1). 'And the Logos became flesh and dwelt among us' (Jn 1:14; Ladd 1993:174). From the immediate literary context, John probably had five things in mind when characterising the identity of Jesus, and the readers have picked this up. Firstly, an important point John wants to make is that this Logos, who is later designated as Jesus, the Son of God (Jn 1:14, 17, 18), is pre-existent. The phrase 'In the beginning' points to a time prior to creation. This phrase certainly alludes to Genesis 1:1: 'In the beginning God created the heavens and the earth'. Jesus himself, in his

35.A change of status often leads to a change in names. Abram's ('father of nations') name was changed to Abraham, 'father of many nations' - a change, which name was changed to Abraham, 'father of many nations' - a
captures his role in the increase of God's people (White 2018:55).

36.According to Luke 1:13, God commanded Zachariah (by mouth of the angle) to call his son John.

37.Each name for God 'is more than a randomly selected label' (Zimmerli 1978:18),

38.Other titles are Lamb of God: 'The next day John saw Jesus coming toward him and said, "Look, the Lamb of God," who takes away the sin of the world!' (Jn 1:29); Holy one of God: 'We have come to believe and know that you are the Holy One of God' (Jn 6:69); Prophet: 'This is indeed the prophet who is to come into the world' (Jn 6:14; see also Jn 4:19); Lord: 'Then some boats from Tiberias came near the place where they had eaten the bread after the Lord had given thanks' (Jn 6:23, 68; see also Jn 1:23; 9:38; 11:2); King of Israel: 'So they took branches of palm tree nd went out to meet him, shouting, "Hosanna! Blessed is the one who comes in the name of the Lord - the King of Israel!"' (Jn 12:13; ch. 19). I Am: 'Jesus said to them, "Truly, truly, I say to you, before Abraham was, I am"' (Jn 8:58). All the 'I am" sayings (Jn 6:35; 8:12; 10:7, 11; 11:25; 14:6:15:1). 
argument with the Jews, refers to his pre-existence, 'Before Abraham was, I am' (Gn 8:58; Ladd 1993:277).

Secondly, John uses the Logos concept to proclaim the deity of Jesus: 'The Logos was with $\left(\pi \rho{ }^{\prime} \varsigma\right)^{39}$ God, and the Word was

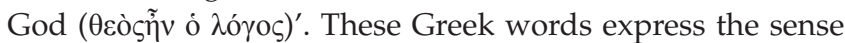
that the Word was divine (Ladd 1993:278). Thirdly, John declares that the Logos was also involved in the creation event. He was the agent through whom God created the universe: 'All things came into being through him, and without him not one thing came into being' $(1: 3,10)$; $[T]$ he world came into being through him' (1:10).$^{40}$ Fourthly, the verb interpreted

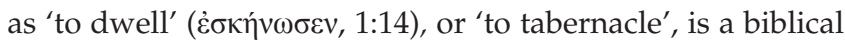
metaphor for the presence of God. This assertion denotes that God himself was existent in the flesh. The fifth connotation of Logos is that the incarnation happened to reveal 'life (1:4), light (1:4-5), grace (1:14), truth (1:14), glory (1:14), even God himself (1:18)' (Ladd 1993:278). These things the readers experienced throughout their reading of John. All five of these aspects affiliated with the title occur in the prologue to prepare the reader for the credibility, faith, acceptance and experience of the other divine titles for Jesus in John.

\section{Messiah (descended from David, King of Israel)}

During the first-century Judaism, ${ }^{41}$ the Jews believed the Messiah would be an anointed, divinely bestowed descendant from David. He would demolish the despised Roman rule and liberate the people of God. He would be the Messiah in the sense that he fulfilled the Old Testament hope of a coming deliverer (Jn 1:45; Ladd 1993:279). In Jesus' recruitment of his first disciples, Andrew told his brother Peter, 'We have found the Messiah' (Jn 1:41; Guthrie 1981:244). John points out that this view was also held by the Samaritans (Jn 4:25, 29; see also Jn 3:28; 7:26, 27, 31, 41-42; 9:22; 10:24; 12:34). Jesus' messiahship even among his early disciples was understood against this background. The readers of John would have come to a different understanding and experience. Their past orientation and understanding of the Messiah would have interacted with the present unfamiliar orientation of the Messiah in John. A restructuring of the reader's messianic beliefs would have taken place - what an experience!

From the perspectives of Jesus' other titles and names, the readers would have understood Jesus' messianic kingship not politically but spiritually (cf. Ladd 1993:279). Already in $4: 26$, John guides the reader indirectly that Jesus is the Messiah when Jesus responds positively to the Samaritan woman's reference, 'I know that Messiah is coming' (who is called Christ). 'When he comes, he will proclaim all things to us' (Jn 4:25). Jesus then acknowledges this with 'I am he'

39.The richness of the phrase $\pi$ póstoveróv "has to be searched out and conveyed by explanation' (Beasley-Murray 2002:10). It can be translated as 'with God' in the sense of 'in the presence of God' (cf. Mk 6:3) or 'in the fellowship of God' (1 Jn $1: 2-3$ ) or even (as the next clause suggests) 'in union with God' (Beasley-Murray 2002:10).

40.In the creation of the universe, God acted alone, I ... alone stretched out the heavens [and] ... by myself spread out the earth' (Isa 44:24). 'The only Eternal One ... God alone created, and no one else had any part in this activity. This is axiomatic for Second Temple Judaism' (Bauckham 2008:34).

41.This was already the case during the centuries prior to Jesus' birth.
(Jn 4:26). It is only as far as 11:27 that John guides the reader explicitly through the confession of Martha that Jesus is the Messiah, the Son of God. 'Lord, I believe that you are the Messiah, the Son of God, the one coming into the world'. In a latter case, messiahship is linked with the title, Son of God, as it is in 20:31 (see also Jn 1:49; Guthrie 1981:245). It is obvious that his messianic kingship is not on the political but on the spiritual level. In the same way, the title 'Christos' is not in itself adequate to designate the person and mission of Jesus. He is not only the Messiah; he is the Messiah who is also the Son of God (Jn 20:31; 1:49; 11:27). Jesus was his name. ${ }^{42}$ Because of the other divine 'names' for Jesus in John, the readers would have experienced in their reading of $\chi \rho ı \tau$ ó $\varsigma$

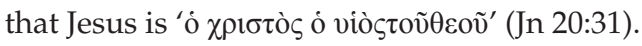

When readers have reached John 19, with the multiple

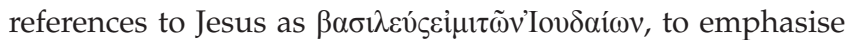
him to be the Christ, they would have been convinced about Jesus' association to be the Messiah. He is the Messiah, but a spiritual Messiah; Jesus is the Christ!

\section{The Son, the Son of God}

This title is undoubtedly the central Christological title for Jesus in John. According to Pollard ([1970] 2005):

$[M]$ ore explicitly and more emphatically than the other New Testament writers does St John declare the divinity of Jesus Christ as eternal Son of God and at the same time the distinction between the Son and the Father. (p. 18)

The Father-Son relationship is expressed over a hundred times in John. These expressions occur during the public ministry of Jesus and 'consistently refer to the personal, official, and essential bond between Jesus a Son and God the Father' (Coetzee 1993:58). The most fundamental element of Jesus' self-revelation is this Father-Son relationship, which can be categorised into Jesus' distinctive union with the Father, his distinctive fellowship with the Father and the distinctive working relationship he experiences with the Father. This is what the early readers could have experienced when they have read the text.

The Jews believed in Jewish monotheism. There is only one God. ${ }^{43}$ Now they hear and experience from Jesus that he is also God, one with God. Their accustomed formulation of monotheism (God) is transcended to a new formulation or reformulation of monotheism (Father and Son). Their 'lived experiences' of the divinity of Jesus is realised when they accept this new truth and a theological restructuring or adjustment of Jesus' divinity takes place. Their understanding of monotheism is redefined.

The Son's distinctive union with the Father: Jesus reveals himself to be one with the Father. The best example to clarify this comes from John (5) where 'the life' is identified with Jesus as person, the life only God has in himself. When Jesus prays to the Father in John (17), he declares his oneness with the Father four

42.It was only when the Gospel spread into the Hellenistic world that Christ became a proper name (Ac 11:26; Ladd 1993:279). See also John (1:17).

43.See the shema and first commandment of the Decalogue. 
times (Jn 17:5, 11, 21, 22). In John 10:38, he expresses in 'the strongest possible terms' to his disciples the mysterious unity between him and the Father, 'the Father is in me, and I in the Father' (see also Jn 14:10f., 20). Therefore, the judgement of the Jews on Jesus was clear, namely, it was a case of 'blasphemy, because you, a mere man, claim to be God' (Jn 10:33; see also Jn 5:18). Jesus' consciousness of his divinity is expressed both in sayings about his unity with the Father, already considered, but especially in the 'I am' sayings (Ladd 1993:286). Through the 'I am' sayings, Jesus claims his divinity and unity with God. The readers would have imagined and experienced the symbols or metaphors used by John when he referred to Jesus' 'I am' sayings. The culmination point in John occurs in the confession of Thomas regarding who Jesus really is: 'My Lord and my God!' (Jn 20:28; Coetzee 1993:56-61). ${ }^{44}$ What an exclamation! Like God, the Son knows everything (Jn 1:48; 2:24-25; 4:16-19, $39 ; 6: 64 ; 13: 1,3,13 ; 16: 19-30)$. He claims to be just in judgement (Jn 5:30). He is the righteous one, in whom there is no sin (Jn $16: 10 ; 1$ Jn $2: 1 ; 3: 7)$; the one who is true, in whom there is no falsehood (Jn 7:18; Rainbow 2014:155). They would have been filled with adoration - what a divine being!

The Son's distinctive fellowship with the Father: In a distinctive way, the Son is the object of the love of the Father. He loved the Son 'before the foundation of the world' (Jn 17:24). Jesus refers to the Father as my Father (Jn 5:17f.; 8:38, 54; 14:2, 21; 20:17). Only he 'came from the Father' (Jn 16:28; 17:8; cf.13:1, 3). In 1:18, John refers to the Son in the bosom of the Father.

This love of the Father for the Son is why the Father has sent him into the world, and they 'have seen his glory, the glory as of a father's only son, full of grace and truth' (Jn 1:14) and that they may also 'see my glory, which you have given me' (Jn 17:24; also Jn 5:20; 15:9f.). The Son knows the Father in a distinctive way; it is the most intimate, mutual, vital fellowship (Jn 6:46; 8:55; 10:15; 17:25) (Coetzee 1993:58-59). He alone has seen God! This divine love becomes an experiential reality when the readers have reached Chapter 19. He died on the cross for them! This is divine experience par excellence!

The Son's distinctive working relationship with the Father: The Son is the Agent of the Father, ${ }^{45}$ validated by the multiple occurrences of the two verbs $\dot{\alpha} \pi \circ \sigma \tau \dot{\varepsilon} \lambda \lambda \omega$ and $\pi \varepsilon \dot{\varepsilon} \mu \omega$. Jesus' conduct of speaking and acting as agent confirms that he has been sent by the Father and with his authority (Jn 3:17; 4:34; 5:23f, 30, 36, 38, etc.). ${ }^{46}$ As Agent sent by the

\section{Explicit references to Jesus as God occur twice in John: in the Johannine prologue (Jn 1:1-3) and John (20:28). These statements are important evidences in the presentation of Jesus as God. This is further supported by the comment in John (1:18

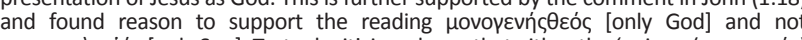

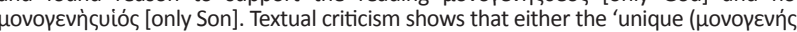 God' or the 'unique Son' has made the Father known. See Borchert (2001:124) for a discussion on the manuscript witnesses. According to him, neither reading is contrary

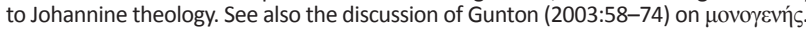 \\ 45.See also footnote 17 .}

46. As the Son of God, Jesus has a divinely appointed mission to fulfil. The most frequently reiterated element in this mission is to mediate life to people. The Son has the same power to confer life as the Father (Jn 5:21). 'For just as the Father has life in himself, so he has granted the Son to have life in himself' (Jn 5:26). Therefore, faith in Jesus as the Son of God ushers in the possession of eternal life (Jn 3:35; faith in Jesus as the Son of God
$6: 40,47 ; 10: 10$; Ladd 1993:285).
Father, all his works are the works of the Father $(5: 17,19)$. He does his works in the name of the Father (10:25); they are 'good works from the Father' (10:32). His whole ministry is dominated by a consciousness that he has been divinely commissioned (Ladd 1993:284). Therefore, the Son could declare, 'The Father who dwells in me does his works' (14:10). The same is true about the words of the Son. Jesus said, 'the word which you hear is not mine, but the Father's who sent me' (14:24; see also 8:28, 40; $12: 50 ; 14: 10 ; 15: 15$; etc.; Coetzee 1993:58). In the end, the readers realised that they have actually experienced God. They have experienced his involvement in their lives when they have become part of the text and examined their lives.

\section{Son of man}

John refers to Jesus 13 times $(1: 51 ; 3: 13,14 ; 5: 27 ; 6: 27,53$, 63; $8: 28 ; 9 ; 35 ; 12: 23,34[$ bis]; 13:31) as 'the Son of Man', a heavenly, supernatural being who incarnated with apocalyptic glory (Ladd 1993:281). Schnackenburg (1968:529-542) sees, in comparison with the Synoptic gospels, some developments in John's use of the Son of man traditions. Higgins (1964:153184) considers the Son of man passages to be the central theme of John's Christology. If this is true, then it is likely that the reader will experience that in this title all the other divine titles converge $\mathrm{e}^{47}$ to substantiate and strengthen even more the conception of the divinity of Jesus. The aspects attached to describe the Son of man may be grouped under the following three groups of statements.

Statements about the origin and destiny of the Son of man: Perhaps, the most important feature of the Son of man on which John focusses is his descent and ascent (Jn 1:51; 3:13). In fact, the descent-ascent schema is integral to John's whole approach to Jesus. He regards this schema as the connecting link between heaven and earth. For John, heaven is the real sphere of the Son of man and not earth. After the completion of his earthly mission, he ascends to God. Ascension is therefore a fundamental part of the Son of man consciousness.

Statements showing the expertise of the Son of man: Some of the passages describe the activities of the Son of man equivalent to those attributed to God (as in 6:27). This implies that the expertise between God the Father and the Son of man is equivalent. This is evident from 8:28 where Jesus asserts that 'I do nothing on my own, but I speak these things as the Father instructed me'. Another equivalent occurs in 12:50, 'What I speak, ..., I speak just as the Father has told $\mathrm{me}^{\prime}$. By these statements, John describes the close connection between the mission of the Son of man and the will and plan of God (cf. Guthrie 1981:286).

Statements predicting a lifting up of the Son of man: The lifting up (vं\%ó $\omega$ ) of the Son of man occurs in John 3:14; 8:28; and 12:32-34. In John 12:33, the lifting up occurs in an

47.Consider Van der Watt's (1991:93-126; see also Loader 1984:188-216) theological pictorial idea. The Logos-title prepared the readers to make sense of Jesus' other titles, and in the Son of Man title the other titles converge. 
editorial comment: 'He said this to show by what death he was to die.' In John's mind, the lifting up of Jesus refers to the raising of Jesus on a cross. In the Johannine context, the meaning of víó $\omega$ is ambivalent. Although it refers primarily to the passion of Jesus, it nevertheless retains the implication of exaltation through the passion and resonates with the glorification motif mentioned in John 13:3-32 and John 17:1 (Guthrie 1981:287). According to John 12:23 and John 13:31 (see also Jn 17:1), the glorification starts on earth, but transcends beyond it (Jn 17:24). It is a particular way of designating the passion in terms of its ultimate consequences. The glorification of the Son of man involved a cross. For John, Jesus' glorification was more important than the shame of the cross. ${ }^{48}$ Together with John and Isaiah (Jn 12:41), the readers have already experienced the glory of the Son of man: 'we have beheld his glory, glory as of the only Son from the Father' (Jn 1:14) that became evident in the Johannine text.

\section{Filling the gaps}

For Iser (1978:168), gaps arise from what is missing in marginal scenes in the text. This normally stimulates readers into filling the gaps with imaginative juxtapositions. They are drawn into the events in the text and will consequently generate what is meant from what is not written. Iser (1978:168) is of the opinion that 'as the unsaid comes to life in the reader's imagination, so the said "expands" to take on greater significance than might have been supposed'.

In John such an identified gap is evident in Jesus' appearances (disappearances, Jn 20:19-29) to his disciples after his resurrection. When the disciples assembled behind closed doors out of fear for the Jews, Jesus appeared to them (Jn 20:19, 26) (see Table 1).

According to both texts, 'Jesus came and stood among them', John says nothing of how Jesus appeared to them or even disappeared. Did he just step through the closed doors or walls? According to the other gospels, Jesus' appearances ${ }^{49}$ were 'sudden'. The reader could then deduct that Jesus would not have come through the closed doors or walls. In John, he most probably also appeared and disappeared instantly.

The readers have to fill the gaps to make sense of Jesus' appearances and disappearances. Where did he come from,

TABLE 1: John 20:19-29.

\begin{tabular}{|c|c|}
\hline $20: 19$ & $20: 26$ \\
\hline $\begin{array}{l}\text { 'When it was evening on that day, the first } \\
\text { day of the week, and the doors of the } \\
\text { house where the disciples had met were } \\
\text { locked for fear of the Jews, Jesus came } \\
\text { and stood among them and said, } \\
\text { "Peace be with you"'. }\end{array}$ & $\begin{array}{l}\text { 'A week later his disciples were } \\
\text { again in the house, and Thomas } \\
\text { was with them. Although the doors } \\
\text { were shut, Jesus came and stood } \\
\text { among them and said, "Peace be } \\
\text { with you"'. }\end{array}$ \\
\hline
\end{tabular}

48.The glory-motif plays an important part in John. John writes that the Son of Man is glorified; John claims in the prologue that 'we have beheld his glory, glory as of the only Son from the Father' $(1: 14)$. The theme is frequently echoed elsewhere (e.g. In 2:11; 5:41f.; 7:18; 8:50f.; 11:4; 12:41; 17:If.; 17:22, 24).

49.'Suddenly Jesus met them and said, "Greetings!"' (Mt 28:9); 'While they were talking about this, Jesus himself stood among them and said to them, "Peace be with you"' (Lk 24:36); 'Then their eyes were opened, and they recognized him; and he vanished from their sight' (Lk 24:31). where did he go? How did the disciples and first Christians understand and experience this? Commentaries are silent about this. These readers probably filled this gap by experiencing Jesus' appearances as theophanies. ${ }^{50}$ God appeared to them twice through the resurrected Christ. Perhaps, they have understood these experiences of Jesus from this perspective based on the following three perspectives: firstly, from the perspective of other theophany occurrences in John; secondly, from the Torah spiritualities fostered in John (see Van der Merwe 2014) ${ }^{51}$; and, thirdly, from the immediate context where Thomas refers to Jesus as 'My Lord and my God'! (Jn 20:28). There are other theophony occurences in John, with probably the most convincing verification of a theophany in John is the incarnation vocabulary, as described in John 1:14 ('And the Word became flesh and lived among us, and we have seen his glory, the glory as of a father's only son, full of grace and truth'). Jesus' appearance on earth was a 'theophany'. God revealed himself in 'human form'. Also in the prologue, John characterises Moses as Israel's lawgiver (Jn 1:17, 45, 5:45-47, 7:19, 22-23, 8:5, 9:28-29) and understands the Mosaic law as an expression of God's

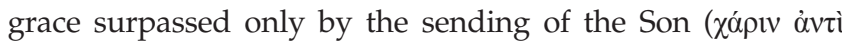

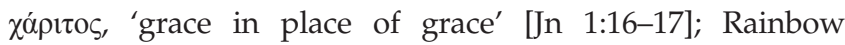
2014:186). After the prologue, the reader finds that the testimony of John the Baptist prepares readers to expect a theophany: 'I am the voice of one crying out in the wilderness, "Make straight the way of the Lord"' (Jn 1:23, quoting Is 40:3; Rainbow 2014:181).

Then in 1:29, Jesus appeared: 'The next day he (John) saw Jesus coming towards him and declared, "Here is the Lamb of God who takes away the sin of the world!"' (4) In another remarkable passage, John takes over an Old Testament theophany text and uses it in reference to Christ. According to John, 'Isaiah said this ${ }^{52}$... because he saw his glory and spoke about him' (Jn 12:41; Rainbow 2014:155). ${ }^{53}$

\section{Torah spirituality}

John is saturated with Torah content (Van der Merwe 2014). The Johannine readers were well acquainted with the content and meaning of the Torah. They could recall the Toraic detail when they heard or read Toraic reflections in John. The Toraic overtones in John are consistently and meticulously Christocentric. John was quite aware of the interpretive Old Testament traditions denoted to the person, ministry, death and resurrection of Jesus as the Messiah (cf. Casselli 1997:17-18; Van der Merwe 2014:3). These readers would have been acquainted with all the theophanies in the

50.Chisholm (2000:815-816) defines 'theophany' as God who appears or reveals himself in human form or elements of nature.

51.See Chisholm (2000:816-818) for a list and discussion of many theophanies from the Torah. The readers could also have been influenced by the Torah spirituality embedded in the Johannine text.

52.'This was to fulfil the word spoken by the prophet Isaiah: "Lord, who has believed our message, and to whom has the arm of the Lord been revealed?" ${ }^{39}$ And so they could not believe, because Isaiah also said, ${ }^{40}$ "He has blinded their eyes and hardened their heart, so that they might not look with their eyes, and understand with their heart and turn - and I would heal them"' (Jn 12:38-40).

53.These theophany references clearly prepare the reader for what is going to happen later in John 20:19-29. 
Torah. God revealed himself to Abraham (Gn 12:7, 15:17, 18:1 19:1-10). God later appeared to Isaac and Jacob to assure them of his intention to bless them in fulfilment of his oath to Abraham (Gn 26:24, 28:12-13, 35:1, 9, 48:3). Of all the people in the Bible, Moses was the most well-acquainted with theophanies (Ex 3:1-6, 24:1-2, 33:11; Dt 34:10; Chisholm 2000:816). These theophanies initially resulted in a spirituality based on awe, wonder, fear of the Lord and devotion. It needed another theophany to realise this into lived experiences for the readers.

\section{The declaration of Thomas}

Thomas became the chief spokesman for the Christological faith when the resurrected Christ appeared to his disciples (Jn 20:28-29). According to Keener (2003:II, 1211; see also Harris 1998:127-128), the scepticism of Thomas makes 'him the ideal proponent of a high Christology by indicating the greatness of the revelation by which he was convinced'. Thomas acted as a spokesperson for the disciples in John 11:16 already. Now, in John 20:28, his exclamation about Jesus, 'My Lord and my God' produces the climactic Christological confession of John. Influenced by Cullmann (1963:308), Keener links the exclamation of Thomas with the

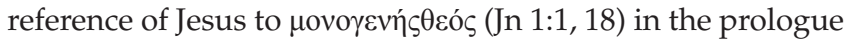
to form an inclusio. He points out that the 'Christological confessions in John build toward a crescendo. In this case, as in the prologue, the confession of Jesus' deity is unmistakable' (Keener 2003:II, 1211; see also Harris 1998:105-29). The readers could have experienced with the disciples Jesus' post-resurrection appearances to them as theophanies. God visited them in the resurrected Christ.

What has been argued in this essay probably converges in the discussion of this last mechanism. For those readers, the appearances of Jesus to his disciples confirmed that Jesus indeed rose from the dead, that there is a God and he is that God! Therefore, these two appearances were two theophanies. It establishes that he is the Christ, the Son of God. Those readers would have experienced his victory over death to ensure the truthfulness of the fundamental doctrine about the divinity of Jesus Christ.

\section{Conclusion}

Any reader of the Gospel of John will admit that John is saturated with doctrine regarding the divinity of Jesus and that the Johannine Greek text is also saturated with brilliant and intelligent vocabulary selections, discourses and narrative by the author. It was pointed out that the Greek text, as well as the cyclic reasoning and pictorial comprehension of theological themes, certainly draws any reader into the text to experience imaginatively what happens with Jesus in the text. The past becomes a present reality for the reader.

The four mechanisms proposed by Waaijman and Iser to determine the spiritualities, fostered by texts, have been applied in this article. The objective was to determine the 'lived experiences' of the divinity of Jesus that were fostered when the early Christians read the Gospel of John.
The readers would have felt as though they were part of the text and they would have felt as though they were part of the events taking place in the text. The readers were drawn into the text. Their imagination enabled them to associate with characters in the text, to follow and listen to Jesus. Certainly, many readers would have accepted the new truths about Jesus' divinity and consequently experienced participation in the familia Dei.

The author succeeds brilliantly and convincingly in reasoning, describing and picturing how God incarnated in Jesus and that Jesus is the Messiah, the Son of God. Through him, God extended the familia Dei so that to 'all who received him, who believed in his name, he gave power to become children of God' (Jn 1:12). This influenced their everyday life in the familia Dei and in their fulfilment of the missio Dei.

\section{Acknowledgements Competing interests}

The author declares that they have no financial or personal relationships that may have inappropriately influenced them in writing this article.

\section{Author's contributions}

D.G.v.d.M is the sole contributor to this article.

\section{Ethical considerations}

This article followed all ethical standards for carrying out research without direct contact with human or animal subjects.

\section{Funding information}

This research received no specific grant from any funding agency in the public, commercial or not-for-profit sectors.

\section{Data availability statement}

Data sharing is not applicable to this article as no new data were created or analysed in this study.

\section{Disclaimer}

The views and opinions expressed in this article are those of the authors and do not necessarily reflect the official policy or position of any affiliated agency of the authors.

\section{References}

Albalaa, P.Y., 2019, Exploring the Johannine spirituality: The experience of God in the Fourth Gospel perceived from the perspective of its Familia Dei, Unpublished doctoral thesis, University of South Africa, Pretoria.

Ashton, J., 1991, Understanding the fourth gospel, Clarendon, Oxford.

Avis, P., 1999, God and the creative imagination, metaphor, symbol and myth, Routledge, New York.

Barton, S.C., 1996, The family in theological perspective, T\&T Clark, Edinburgh.

Bauckham, R., 2008, Jesus and the God of Israel: God crucified and other studies on the New Testament's Christology of divine identity, Eerdmans, Grand Rapids, MI.

Beasley-Murray, G.R., 1999, John, Word, Incorporated, Dallas, TX.

Beasley-Murray, G.R., 2002, John, Word Incorporated, Dallas, TX. 
Bird, M., Evans, C.A., Gathercole, S.J., Hill, C.E. \& Tilling, C., 2014, How God became Jesus. The real origins of belief in Jesus' Divine nature, Zondervan, Grand Rapids, MI.

Boismard, M.-E., 1993, Moses or Jesus. An essay in Johannine Christology, Fortress Press, Minneapolis, MN.

Borchert, G.L., 2001, John 1-11, Broadman \& Holman Publishers, Nashville, TN (New American Commentary).

Borgen, P., 1968, 'God's agent in the fourth gospel', in J. Neusner (ed.), Religions in antiquity, pp. 137-148, Brill, Leiden.

Brown, R.E., 1975, The gospel according to John, vol. I, A new translation with introduction and commentary, Geoffrey Chapman, London.

Bühner, J.A., 1977, Der Gesandte und sein Wegim 4. Evangelium, Mohr, Tübingen.

Bultmann, R., 1953, Theologie des Neuen Testaments, Mohr, Tübingen.

Bultmann, R., 1973, The Johannine Epistles, Fortress Press, Philadelphia, PA.

Casselli, S.J., 1997, 'Jesus as eschatological Torah', Trinity Journal 18(1), 15-41.

Chisholm, R.B., 2000, 'Theophany', in T.D. Alexander \& B.S. Rossner (eds.), New Dictionary of biblical theology, pp. 815-819, Inter-Varsity Press, Leicester.

Coetzee, J.C., 1993, 'The theology of John', in A.B. du Toit (ed.), The Gospel of John Hebrews to revelation: Introduction and theology, Guide to the New Testament $\mathrm{VI}$ pp. 40-77, N.G Kerkboekhandel, Halfway House.

Cullmann, O., 1963, The Christology of the New Testament, transl. S.C. Guthrie \& A.M. Hall, SCM, London.

Culpepper, R.A., 1983, Anatomy of the Fourth Gospel. A study in literary design, Fortress Press, Philadelphia, PA.

Ehrman, B.D., 2014, How Jesus became God: The exaltation of a Jewish Preacher from Galilee, HarperOne, New York.

Gnilka, J., 1994, Theologie des Neuen Testaments, TheologischerKommentarzumNeuen Testament (Supplementband 5), Herder, Freiburg.

Goppelt, L., 1982, Theology of the New Testament, vol. II, transl. J. Alsup, Eerdmans, Grand Rapids, MI.

Gunton, C.E., 2003, Father, son and Holy Spirit: Essays toward a fully trinitarian theology, T\&T Clark, London.

Guthrie, D., 1981, New Testament Theology, Inter-varsity Press, Leicester.

Harris, M., 1998, Jesus as God: The New Testament use of Theos in reference to Jesus, Baker, Grand Rapids, MI.

Hengel, M., 1983, Christology and New Testament Chronology: A problem in the history of earliest Christianity, in between Jesus and Paul, SCM, London.

Higgins, A.J.B., 1964, Jesus and the son of man, Butterworth, London.

Hurtado, L.W., 2003, Lord Jesus Christ. Devotion to Jesus in Early Christianity, Eerdmans, Grand Rapids, MI.

Iser, W., 1978, The act of reading: A theory of aesthetic response, Johns Hopkins University Press, Baltimore, MD.

Johnson, T.F., 1993, 1, 2, and 3 John, Hendriksen Publishers, Peabody, MA.

Jordan, W.J., 1974, 'Aristotle's concept of Metaphor in Rhetoric', in K.V. Erickson (ed.) Aristotle: The classical heritage of rhetoric, pp. 235-250, Scarecrow Press, Metuchen, NJ.

Juel, D.H., 1997, 'The trinity in the New Testament', Theology Today 54(3), 312-324. https://doi.org/10.1177/004057369705400303

Keener, C.S., [2003] 2005, The Gospel of John. A commentary, 2 Vol., Hendrickson Publishers, Peabody, MA.

Keener, C.S., 2003, The Gospel of John: A Commentary, vol. 11, Hendrickson, Peabody, MA

Kim, S., 2017, The spirituality of following Jesus in John's Gospel: An investigation of Akolouthein and Correlated Motifs, Pickwick Publications, Eugene, OR.

Koester, C.R., 2008, The word of life. A theology of John's gospel, Eerdmans, Grand Rapids, MI.

Kuhl, J., 1967, Die Sendung Jesu und der Kirche nach dem Johannes-Evangelium, Steyler Verlag, Siegburg.

Kysar, R., 1975, The fourth evangelist and his gospel, Augsburg Publishing House Minneapolis, MN.

Kysar, R., [1976] 2007, John the maverick gospel, Westminster John Knox Press, Louisville, KY.

Ladd, G.E., 1977, A theology of the New Testament, Eerdmans, Grand Rapids, MI.

Ladd, G.E., 1993, A theology of the New Testament, Eerdmans, Grand Rapids, MI.

Lindars, B., 1981, The Gospel of John The New Century Bible Commentary Eerdmans, Grand Rapids, MI.

Loader, W.R.G., 1984, 'The central structure of Johannine Christology', New Testament Studies 30, 188-216. https://doi.org/10.1017/S0028688500013758

MacCormac, E.R., 1976, Metaphor and myth in science and religion, Duke University Press, Durham.

Meeks, W.A., 1972, 'The man from heaven in Johannine Sectarianism', Journal of Biblical Literature 91, 44-72. https://doi.org/10.2307/3262920

Meeks, W.A., 1986, 'The man from heaven in Johannine Sectarianism', in Ashton, J. (ed.), The Interpretation of John, SPCK, London.
Mercer, C., 1990, 'Apostellein and Pempein in John', New Testament Studies 36, 619-624. https://doi.org/10.1017/S0028688500019780

Mercer, C., 1992, 'Jesus the Apostle: Sending and the theology of John', Evangelical Theological Society Journal 35(4), 457-462.

Neyrey, J.H., 2007, The gospel of John, Cambridge University Press, Cambridge.

Nicholson, G.C., 1983, Death as departure. The Johannine descent-ascent schema, Scholars, Chico, CA.

Peterson, R.A., 2013, 'Union with Christ in the Gospel of John', Presbyterian 39(1), 9-29.

Pollard, T.E., 1970, Johannine Christology in the early church, Society of New Testament Studies Monograph Series 13, Cambridge University Press, Cambridge.

Pryor, J.W., 1991, 'The Johannine son of man and the descent-ascent', Theologica Society 34(3), 341-351.

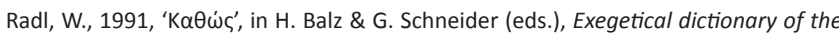
New Testament, vol. II, pp. 226-228, Eerdmans Publishing Company, Grand Rapids, MI.

Rainbow, P.A., 2014, Johannine theology: The gospel, the epistles and the apocalypse, IVP Academic, Downers Grove, IL.

Richard, E., 1985, 'Expressions of double meaning and their function in the gospel of John', New Testament Studies 31(1), 96-112. https://doi.org/10.1017/ S0028688500012947

Ridderbos, H., 1997, The Gospel of John: A theological commentary, Eerdmans, Grand Rapids, MI.

Robbins, V.K., 2008, 'Rhetography: A new way of seeing the familiar text', in C.C. Black \& D.F. Watson (eds.), Words well spoken: George Kennedy's rhetoric of the New Testament, pp. 1-26, Baylor University Press, Waco, TX.

Sanders, J.N. \& Mastin, B.A., 1975, The gospel according to St. John from Blacks' New Testament commentaries, Adam and Charles Black, London.

Schnackenburg, R., 1965, The Gospel according to St John, vol. 1, Burns \& Oates, London.

Schnackenburg, R., 1968, The Gospel according to St John, vol. 2, Burns \& Oates, London.

Schneiders, S.M., 1982, 'The paschal imagination: Objectivity and subjectivity in New Testament interpretation', Theological Studies 43(1), 52-68. https://doi. org/10.1177/004056398204300103

Schnelle, U., 2001, 'Recent views of John's Gospel', Word \& World XXI(4), 352-359.

Shibles, W.A., 1972, Essays on metaphor, The Language Press, Whitewater, WI.

Stander, A.J., 2017, 'Menein as key to a mystical reading of John 15', Unpublished doctoral thesis, University of the Free State, Bloemfontein.

Strecker, G., 1996, The Johannine Letters: A commentary on 1, 2, and 3 John, Fortress Press, Minneapolis, MN.

Thompson, M.M., 1999, 'The living father', in A. Reinhartz (ed.), God the father in the gospel of John, Semeia 85, pp. 19-32, Society of Biblical Literature, Atlanta, GA.

Thompson, R.P., 2000, 'Community in conversation: Multiple readings of scripture and a Wesleyan understanding of the church', Wesleyan Theological Journal 35(1) 200-215.

Thompson, M.M., 2014, 'The Gospel of John in early trinitarian thought: The unity of God in John, Irenaeus and Tertullian', Journal of Early Christian History 4(2) 154-166. https://doi.org/10.1080/2222582X.2014.11877309

Van der Merwe, D.G., 1996, 'Discipleship in the fourth gospel', Unpublished doctoral thesis, University of Pretoria, Pretoria.

Van der Merwe, D.G., 2001, 'Imitatio Christi in the fourth gospel', Verbum et Ecclesia 22(1), 131-148. https://doi.org/10.4102/ve.v22i1.628

Van der Merwe, D.G., 2009, 'Family metaphorics: A rhetorical tool in the epistle of 1 John', Acta Patristica et Byzantina 20(1), 89-108. https://doi.org/10.1080/102264 86.2009.11879098

Van der Merwe, D.G., 2014, 'Old Testament spirituality in the gospel of John', Verbum et Ecclesia 35(1), Art. \#837, 1-9. https://doi.org/10.4102/ve.v35i1.837

Van der Merwe, D.G., 2015, '1 John: "Effects" in biblical texts that constitute "lived experiences" in the contemplative reading of those texts', In die Skriflig 49(2), Art. \#1930, 1-9. https://doi.org/10.4102/ids.v49i2.1930

Van der Merwe, D.G., 2017, 'Conceptualising holiness in the gospel of John: The en route and character of holiness (Part 2)', HTS Teologiese Studies/Theological Studies 73(3), 1-11, a4610. https://doi.org/10.4102/hts.v73i3.4610

Van der Watt, J.G., 1991, 'Die Woord het Mensgeword: 'n Struktureleuiteensetting van die teologie van die Johannesevangelie', in J.H. Roberts, W.S. Vorster, J.N. Vorster \& J.G. Van der Watt (reds.), Teologie in konteks, bl. 93-126, Orion, Pretoria.

Van der Watt, J.G., 2000, Family of the King. Dynamics of metaphor in the gospel according to John, Biblical Interpretation, Series 47, Brill, Boston, MA.

Waaijman, K., 2002, Spirituality: Forms, foundations, methods, Peeters Publishers, Dudley.

Waldstein, M., 1990, 'The mission of Jesus and the disciples in John', Communio: International Catholic Review 17(3), 311-333.

White, T., 2018, 'What is in a name, then?', The Way 57(1), 51-60.

Zimmerli, W., 1978, Old Testament theology in outline, T\&T Clark, Edinburgh. 